University of Massachusetts Amherst

From the SelectedWorks of Benjamin Bailey

2000

Social/Interactional Functions of Code Switching among Dominican Americans

Benjamin Bailey 


\title{
SOCIAL/INTERACTIONAL FUNCTIONS OF CODE SWITCHING AMONG DOMINICAN AMERICANS
}

\author{
Benjamin Bailey
}

\begin{abstract}
Linguistic assumptions of an individual speaker-hearer are subtly reflected in analyses of code switching that assign switches to "conversational strategies," categories that are treated as if they existed prior to, and independent of, actual interactions. While such categories provide convenient rubrics for many common and significant social functions of code switching, they fail to capture the interactionally emergent functions of many switches. In this article I highlight such locally emergent functions of code switching among Dominican American high school students by examining several transcripts of intra-group, peer interaction from a conversation analytic perspective. Many switches in such peer interaction are better explained in terms of the sequential, conversational management activities achieved by interlocutors than by pre-defined categories of switches.
\end{abstract}

Keywords: Code switching, Dominican Americans, Interaction, Contextualization, Discourse strategy.

\section{Introduction}

Code switching is commonly defined in terms of its outward form, e.g. as the alternation of codes in a single speech exchange (Gumperz 1982: 59; Heller 1988: 1). This unitary definition in terms of form veils the diversity of practices and meanings that code switching encompasses and the multiple perspectives from which it can be analyzed. Like many language practices, code switching is polysemous and multifunctional (Silverstein 1976), and code switching practices and functions vary both across and within communities (e.g. Gal 1988; Heller 1988). Consequently, approaches to code switching - and findings - have varied widely, depending on researchers' theoretical and methodological orientations, and the characteristics of the code switching community(ies) studied.

Among the foci of code switching research have been 1) $\operatorname{syntax}^{1}, 2$ )

${ }^{1}$ Many studies of code switching have focused on the grammaticality of code switching (e.g. McClure 1977; Poplack 1982; Sankoff \& Poplack 1981; Lipski 1985), countering the notion that it represents an unsystematic, degenerate form of language. Classification of switches in such studies are based on syntactic criteria, yielding such categories as "tag-switching," "inter-sentential switching," and "intra-sentential switching" (Poplack 1982). Such studies also address linguistic/grammatical constraints on code switching (e.g. Pfaff 1979; Sankoff \& Poplack 1981; Clyne 1987), seeking rules to describe allowable switching sites. A common thread of syntactic approaches to code switching is that they address the syntactic sites where code switching can occur, but they generally do not address why a code switch might occur to begin with. 
discourse/conversation management functions, and/or 3) more global social/metaphorical functions. ${ }^{2}$ While syntactic approaches to code switching generally focus on allowable code switching sites, social, or pragmatic, approaches to code switching have emphasized the multiple social and discursive functions of code switching. The best-known and most widely discussed of social typologies are the categories "situational code switching" and "metaphorical code switching" described by Blom \& Gumperz (1972), and later expanded and modified by Gumperz (1982) in terms of "conversational code switching."

Gumperz (1982) and others (e.g. Myers-Scotton 1993b; Zentella 1997) have used the term "strategies" to describe functions of code switching. While the term "strategy" captures the notion of skilled performance in code switching, it can also imply a fixedness, intentionality, and prior planning. The notion that strategies pre-exist actual interactions is fostered by typologies or taxonomies of code switching that decontextualize and reify functions of code switching. This perspective implicitly assumes particular, Western theories of mind, intentionality, and meaning that have been repeatedly criticized by anthropologists (e.g. Keenan 1976; Duranti 1993; Rosaldo 1982; Stroud 1992).

The notion of fixed strategies in code switching has also been challenged from a more ethnomethodological and conversation analytical perspective, most notably by Auer and collaborators (Auer 1984, 1988, 1995; Auer 1998 (ed.); particularly Alfonzetti 1998 and Wei 1998; see also Meeuwis and Blommaert 1994):

Participants apparently do not interpret code-switching or transfer by subsuming a given instance under one of a pre-established set of types; instead, they dispose of certain procedures for coming to a local (situated) interpretation where the exact meaning or function of language alternation is a result of both contextual information and these more general procedures. (Auer 1984: 11)

Central to this approach is the notion of on-going interaction as a particular context in-andof-itself:

...whatever language a participant chooses for the organization of his/her turn, or for an utterance which is part of the turn, the choice exerts an influence on subsequent language choices by the same or other speakers. (Auer 1984: 5).

Code switching, like other forms of talk, is "doubly contextual" (Heritage 1984: 242), both 1) relying on existing sequential context for its production and interpretation, and 2) shaping the sequential context in which subsequent utterances will be produced and interpreted.

This tradition builds on Gumperz's (1982) insight that "conversational code switching" is multifunctional, serving both global social/metaphorical functions and local discourse management functions. Thus in addition to whatever socio-political meanings code switches may carry, they can serve as contextualization cues (Gumperz 1982, 1992) to mark, for example, a particular sequence of speech as a quotation or to emphasize or

${ }^{2}$ Romaine (1995) points out that the common bipartite division of code switching studies - syntax vs. social functions - is neatly indexed by Myers-Scotton's (1993a, 1993b) dual volumes on code switching, one emphasizing grammatical structures, the other focusing on social motivations for code switching. Conversational/discourse management functions of code switching, in contrast, are not always differentiated so clearly from more metaphorical, socio-political functions. 
qualify a message. In terms of local discourse management, code switching can thus be a metadiscursive activity that "signals contextual information equivalent to what in monolingual settings is conveyed through prosody or other syntactic or lexical processes" (Gumperz 1982: 98). ${ }^{3}$

Data presented here show that many switches among Dominican American high school students are best understood in terms of the local, conversational management activities that speakers mutually negotiate. Speakers are not selecting from among preexisting, socio-metaphorical code switching categories in their talk, but rather are giving meaning to code switches by using them as communicative resources to get the work of everyday talk and interaction done. Speakers, whether in bilingual or monolingual conversation, must work to establish and maintain a degree of intersubjectivity, and code switching becomes a resource for doing this, e.g. through highlighting such conversational structures as repair (Schegloff, Jefferson, \& Sacks 1977), proffered candidate understandings, or offer/announcement sequences (Atkinson \& Drew 1979).

In this article, I first emphasize the interactional nature of code switching, reanalyzing several published examples of code switching in order to illustrate their locally negotiated and emergent functions. I then review three of the social and pragmatic levels at which code switching functions. Researchers have described aspects of these three levels under various names and from various analytical perspectives, often in ways that veil the underlying commonalties of their findings. Highlighting the common bases of these typologies helps to situate the type of unmarked discourse contextualization switching on which I focus in this article. I then review some correlations of these major functions with the larger socio-political contexts in which they occur in order to further situate the Dominican American data presented. I illustrate the inherent multifunctionality of switches within a particular community with two examples of switching. Finally, I analyze in more detail three transcripts of Dominican America peer interaction from a conversation analytic perspective in order to highlight the locally negotiated nature of many switches and their discourse contextualization functions.

\footnotetext{
${ }^{3}$ The boundaries between code switching and switching among varieties or styles are not always clear (Alvarez-Cáccamo 1998; Franceschini 1998). Romaine (1995: 170-1), for example, refers to switches to conversational historical present tense in narratives (Wolfson 1982), as "monolingual code-switching," and it has long been noted that speakers move among varieties as they speak, e.g. between African American Vernacular English (AAVE) and other varieties of English (Labov 1971: 462). Morgan (1996: 414-5) describes how often-subtle differences between unmarked American English and AAVE, i.e. metaphorical code switches, are exploited by speakers alternating among forms to achieve distinctive social meanings. Some of these AAVE discursive activities, e.g. loud talking (relying on volume) or marking (relying on pitch), do not rely on segmentable features such as lexicon, morphology, or syntax that are frequently used to define AAVE and differentiate it from other American English varieties. Depending on one's definitions of code/code-switching and the social indexicality of particular forms, it can be difficult to distinguish between monolingual speech and code switching.
} 


\section{Data}

The transcripts of naturally occurring interaction among Dominican Americans ${ }^{4}$ that are presented here come from videorecordings made of students at a Providence, Rhode Island public high school. The school is approximately 60\% Hispanic, with Dominicans comprising the largest single ethnic/national group. Six Dominican American subjects, aged 16 to 18 , were repeatedly observed and interviewed over the course of a year, and were videorecorded throughout a school day and in one non-school context. Selected segments of talk were transcribed in detail following conversation analytic conventions (Heritage \& Atkinson 1984; See Appendix A for transcription conventions). Bilingual Dominican American consultants, including the six principal subjects, aided in the transcription and translation of talk and offered interpretations and explanations of interactions.

\section{Code switching as an interactional phenomenon}

The sentence-based approach of much linguistic analysis, with its assumption of an individual speaker-hearer (e.g. Bloomfield 1933; Chomsky 1965), has deterred researchers, until recently (e.g. Duranti \& Goodwin 1992; Ochs, Schegloff, \& Thompson 1996) from focusing on the interactional nature of language. This orientation has been both reflected and reproduced by transcription schemes (cf. Ochs 1979) that fail to attend to the interactional work of actors, and until recently, by code switching data that has been limited to audio-, rather than audio-video recordings. As shown by Goodwin (Goodwin 1981; Goodwin \& Goodwin 1992), the interactive shaping of individual turns, and even clauses, for example, is frequently only evident with documentation of participants' gaze, head nods, bodily orientation, etc.

Analysis of code switching as an interactional phenomenon, in which patterns of switches are explained in terms of interactional structures and exigencies, has been led by Auer (1984, 1988, 1995, 1998). Auer's (1984) seminal Bilingual Conversation described itself as an "attempt to flex the muscles of conversation analysis as much as possible" (1984:6) in presenting a model of code switching. Despite this emerging tradition (e.g. Sebba 1993; Li Wei 1994, Auer (ed.) 1998), many analyses that focus on contextualization or framing functions of code switching continue to present switches outside of their sequential, interactional context. Such approaches implicitly treat intersubjectivity as a given and de-emphasize the constant, on-going work that social actors do to achieve a degree of coordinated social action and mutual understanding. Zentella (1997), for example, focuses on contextualization strategies in describing 21 categories of conversational code switching among New York Puerto Ricans. While many of her examples of code switches make evident the directly interactional nature of switches, this interactional work, much of it nonverbal, is not the basis of categorization, as can be seen

\footnotetext{
${ }^{4}$ I use the term "Dominican American" in a specific sense: To refer both to the United States-born children of Dominican immigrants (i.e. the "second generation"), and to Dominican-born children who came to the United States by age 8 (whom some researchers call the "1.5 generation"). By their mid- to late-teens, such Dominican-born individuals are English-dominant, like their United States-born peers.
} 
in examples 1-3.

(1)

Category: "Future Referent Check and/or Bracket"

Le dió con irse para - you know Lucy? - para la casa del papá de Lucy.

['She up and decided to go to-...-to Lucy's father's house.'] (Zentella 1997: 94)

In this example, the end of the bracketed activity in English - and subsequent switch back into Spanish - is likely triggered by a nod or other acknowledgment from the interlocutor that he/she does, in fact, know Lucy. In some examples, the interactional triggering of switches is explicitly addressed by participants:

(2)

Category: "Aggravating Requests"

Ella tiene - -Shut up. Lemme tell you. ['She has - ...']

(3)

Category: "Attention Attraction"

Éste se está llenando, lookit, Ana. ['This one is filling up,...'] (Zentella 1997: 95)

In both of these cases, speaker's switches co-occur with explicit reference to an interlocutor's behavior: The failure to listen appropriately in the first case and the failure to orient one's gaze/attention properly in the second case. These switches are not triggered by pre-existing strategies, but rather by spatially and temporally local behavior. Coordinating social action and maintaining a degree of intersubjectivity are ever-present exigencies in naturally occurring talk and interaction, and interlocutors visibly attend to these exigencies.

Formal linguistic bias leads to emphasizing the sentence as the unit of analysis even when other units better explain data. In analyzing the grammar of code switching, Zentella (1997) treats the following utterance, for example, as a "sentence" with a code switch at an adverbial phrase:

(4)

Ráscame allí, allí mismo, a little bit down. [('Scratch me there, right there...'] (Zentella 1997: 118)

The itchy speaker, however, is clearly saying alli mismo ['right there'] and "a little bit down" - and thereby code switching - in response to the scratcher's behavior. From an interactional or conversation analytical perspective, this utterance consists of at least five interactional moves, two of them by a participant who is made invisible in this sentencebased account:

1) First Pair Part: Request: Ráscame allí ['Scratch me there']

2) Second Pair Part: Acceptance and Enactment: Interlocutor scratches speaker on a spot, displaying candidate understanding of allí ['there']. 
3) Speaker confirms candidate understanding of allí as the correct one: Alli mismo ['right there']

4) Scratcher changes scratch site (and/or itch migrates).

5) Speaker other-initiates repair of scratching behavior: "a little bit down"

The linguistic bias toward sentence-based syntax leads to a categorization of this switch based on syntactic constituents as if these three utterances were produced by a speaker in a social vacuum. While these three successive utterances can be juxtaposed and presented as a single awkward sentence, they are better understood as turns or turn constructional units in an interactional, sequential, locally managed context (Sacks, Schegloff, \& Jefferson 1974). From this perspective, focus of analysis shifts from trying to fit code switches into pre-established linguistic types to uncovering the local discursive and interactional processes and contextual features to which participants themselves visibly attend (cf. Auer 1984: 11).

\section{Locating discourse contextualization among social dimensions of code switching}

More than any other analyst, John Gumperz (Blom \& Gumperz 1972; Gumperz \& Hernández-Chavez 1975; Gumperz 1982) stimulated interest in social functions of code switching, and many aspects of his formulations have continued to shape research. Many language analysts through the 1960's, including those focusing on bilingualism (e.g. Weinreich 1953: 73), had treated code switching as linguistic interference, with connotations of linguistic, social, or cognitive deficit. Gumperz, in contrast, approached code switching as a form of skilled performance (Myers-Scotton 1993b: 74) through which individual social actors could communicate various social and pragmatic meanings. Rather than representing a linguistic deficit, mongrelization, or degeneration (Hill \& Hill 1986: 55), code switching represented a discourse strategy, i.e. a complex, systematic, and meaningful behavior. This perspective and terminology served to counter implicit notions of linguistic purism that have dominated Western thought about language for hundreds of years (Aarsleff 1982).

Blom \& Gumperz' (1972) situational code switching vs. metaphorical code switching represents what has been the most widely discussed and influential categorization of switches based on social function. Situational switching involves a direct relationship between code use and observable factors of the situation:

Distinct varieties are employed in certain settings (such as home, school, work) that are associated with separate, bounded kinds of activities (public speaking, formal negotiation, special ceremonials, verbal games, etc.) or spoken with different categories of speakers (friends, family members, strangers, social inferiors, government officials, etc.). (Gumperz 1982: 60)

Situational code switches occur in response to changes in the situations, e.g. the approach of an individual who does not understand the language being spoken, or as interlocutors move to a different institutional setting associated with a distinct code. Such switches are relatively indexically presupposing (Silverstein 1976) in that they presuppose changes in context that are apparent to participants. It is this pattern of code switching that is characteristic of diglossia (Ferguson 1959) and the compartmentalization of codes by social 
domains (Fishman, Cooper, \& Ma 1971). In such situations, particular codes are relatively closely associated with particular social roles, relationships, institutions, activities, and ideologies.

Blom \& Gumperz' (1972) metaphorical code switching is defined precisely by the violation of expected code-situation relationships, i.e. code switches that occur without any observable change in the physical situation:

The context in which one of a set of alternates [codes] is regularly used becomes part of its meaning, so that when this form is then employed in a context where it is not normal, it brings in some of the flavor of this original setting. (1972: 425)

Blom \& Gumperz (1972: 425-6) give the example of a customer and clerk switching from a more formal language variety used in their business transaction to a less formal variety for subsequent, more personal talk, which may "add a special social meaning of confidentiality or privateness to the conversation" (1972: 425). In such metaphorical switching, then, changes in language effect changes in context and social roles, without apparent prior changes in the physical or outward context. Such switches are thus relatively indexically creative or entailing (Silverstein 1976).

In later work, Gumperz (1982) uses the term "conversational switching" in place of the term "metaphorical" switching. The assumption that non-situational switching is metaphorical relies on a diglossic notion of 'we' vs. 'they' codes which is only present in situations where codes are compartmentalized (e.g. Kroskrity 1993) or politically charged (e.g. Heller 1992), and it fails to explicitly define the link(s) between code choice and social meaning. Blom and Gumperz (1972: 425), for example, rely on a vague metaphor to describe this code-meaning link: A switch to a variety associated with informal interactions "brings in some of the flavor of this original setting".

Gumperz's (1982) conversational switching can serve metaphorical functions and/or local discourse management functions. ${ }^{5}$ By attributing discourse management functions to code switching, Gumperz tied the study of code switching to the tradition that examines the multiple means and activities through which talk continuously comments on itself and itself provides context for its interpretation (Duranti \& Goodwin 1992). Approaches to such metadiscursive behavior have included work by Bateson (1972), Goffman (1974), and Hymes (1974) on frames and keys, Goffman (1981) on footing, and work in conversation analysis (e.g. Schenkein (ed.) 1978; Psathas (ed.) 1979). Implicit in such work is a notion

${ }^{5}$ Gumperz (1982: 75-81) enumerates six specific functions of conversational code switching: 1 ) quotation, 2) addressee specification, 3) interjection, 4) reiteration, 5) message qualification, and 6) personalization vs. objectivization. This conversational code switching typology groups together communicative phenomena that operate on different levels and are defined in different terms, as if they were parallel in type. The category "interjection," for example, is labelled and defined in terms of the switched element's syntactic function in a sentence. The category "addressee specification" is defined in terms of a local interactional function of switching without reference to surface form. The catergory, "quotations" is defined in terms of its framing of reported speech, while "reiterations" are defined in terms of referential functions as well as the metadiscursive function of "emphasis." "Message qualification" is labelled specifically in terms of its metadiscursive function but is described in terms of sentence structure ("qualifying constructions such as sentence and verb complements or predicates following a copula" (1982: 79)). Finally, "personalization vs. objectivization" is not defined in terms of surface shape or local contextualization functions but in terms of more abstract metaphorical function (cf. Auer 1995: 120-1). 
of speech as action (Austin 1962; Searle 1969), i.e. that language is not just a system of reference but simultaneously a mode of action at various levels with which individual actors constitute social worlds (Garfinkel 1967).

Unlike situational or metaphorical switches, conversational management switches do not necessarily co-occur with external changes in the context or effect significant shifts in sociocultural framework. Individual switches serve instead as contextualization (Gumperz 1982, 1992) cues to mark off quotations, interjections, etc. from surrounding speech. In such unmarked discourse contextualization switching, conventionalized associations between particular codes and social worlds are at least partially suspended by participants (although not necessarily by non-member bystanders). Shifts in codes thus function as signals that there is a concurrent shift in speech activity but not necessarily in socio-cultural interpretive framework. The direction of the shift is not necessarily the important dimension for discourse contextualization, but rather the act of alternation itself.

\section{Code switching functions across various analysts' typologies}

Gumperz's characterizations of "situational," "metaphorical," and "conversational" (in the sense of unmarked discourse contextualization) switching serve as a heuristic for highlighting particular functions of code switching and should not be understood as representing entirely discrete or manifest types. Gumperz (1982: 96), himself, argues that "to say that code switching conveys information doesn't mean that a switch can be assigned a single meaning." Many analysts have argued that code switching is inherently polysemous and ambiguous (e.g. Stroud 1992, 1998) and others have pointed out that categories such as "metaphorical" and "situational" are better understood as falling along a continuum rather than as discrete types (Auer 1984; Myers-Scotton 1993b).

At the same time, however, these three functional dimensions of code switching have proven robust: Despite differences in theoretical orientation and the labels given to categories of switches, prominent analysts' code switching functions/categories overlap significantly with the three of Gumperz. The ways in which these typologies of code switching overlap is represented in Table 1.

Auer (1984: 12) divides code switches into those that provide "cues for the organization of the ongoing interaction" and those that provide cues "about attributes of the speakers." Although Auer emphasizes interlocutors' procedures for arriving at interpretations, rather than pre-existing taxonomies, the polarity he uses - "participant related" vs. "discourse related" switching - rephrases the distinction between situational code switching (in which switches can be explained in terms of language facility of interlocutors) and unmarked discourse contextualization switching, an aspect of Gumperz's (1982) "conversational" code switching. Auer (1984) describes no category parallel to "metaphorical" switching. As will be described below, this may be a function not so much of theoretical approach, but of the specific group he investigated, among whom metaphorical switching is less common and prominent than other types. 
Table 1. Overlapping typologies of code switching

\begin{tabular}{|c|c|c|c|}
\hline \multirow{2}{*}{ Analyst } & \multicolumn{3}{|c|}{ Functional category } \\
\hline & Situational & Metaphorical & $\begin{array}{l}\text { Unmarked } \\
\text { discourse } \\
\text { contextualization }\end{array}$ \\
\hline $\begin{array}{l}\text { Blom \& Gumperz } \\
\text { (1972) }\end{array}$ & "situational" & "metaphorical" & $\varnothing$ \\
\hline Gumperz (1982) & $\begin{array}{l}\text { "diglossia/ } \\
\text { situational" }\end{array}$ & "conversational" & "conversational" \\
\hline Auer (1984) & $\begin{array}{l}\text { "participant } \\
\text { related" }\end{array}$ & $\varnothing$ & "discourse related" \\
\hline $\begin{array}{l}\text { Myers-Scotton } \\
\text { (1993b) }\end{array}$ & $\begin{array}{l}\text { "sequential } \\
\text { unmarked choices" }\end{array}$ & $\begin{array}{l}\text { "code switching as } \\
\text { a marked choice" }\end{array}$ & $\begin{array}{l}\text { "code switching as } \\
\text { the unmarked } \\
\text { choice" }\end{array}$ \\
\hline Zentella (1997) & $\begin{array}{l}\text { "on the spot } \\
\text { observables" }\end{array}$ & $\varnothing$ & $\begin{array}{l}\text { "in the head } \\
\text { communicational } \\
\text { factors" }\end{array}$ \\
\hline
\end{tabular}

Myers-Scotton (1993b) approaches code switching in terms of what she calls its "social motivations." She categorizes code switches in terms of their relative "markedness," i.e. the degree to which they are treated as if the speaker is doing something of social significance by switching, a significance that would not have been conveyed by monolingual discourse. Although Myers-Scotton (1993b) categorizes switching patterns around markedness, her three main categories still coincide with the three types delineated by Gumperz and echoed by others ${ }^{6}: 1$ ) In her code switching as a "sequence of unmarked choices" speakers switch "when situational factors change with the interaction" (1993b: 149). In other words, these are situational switches. 2) In her "code switching as a marked choice" switches serve to constitute an alternate communicative framework, what she calls a "rights-and-obligations set" (1993b: 84). Such switches, which effect changes in context and social roles, are what others have called metaphorical switches. 3) "Code switching as the unmarked choice" occurs among bilingual peers in particular situations. Such switches do not occur in response to shifts in situation, nor do they effect larger socio-cultural shifts in communicative context, but rather "may have specific rhetorical functions within the

${ }^{6}$ This overlap between Myers-Scotton's (1993b) categories and those of other analysts is all the more remarkable because she presents her model of code switching as universal and innate (and implicitly ahistorical), while most sociological and anthropological analysts emphasize the variability and socio-political specificity of code switching (see Meeuwis \& Blommaert 1994 for an extended discussion and critique of Myers-Scotton 1993b). 
conversational text" (1993b: 149). This is the unmarked discourse contextualization type of switching described by Gumperz (1982) under the category "conversational code switching," and on which Auer (1984) focuses under the rubric "discourse related" code switching. Myers-Scotton's (1993b) fourth category, "exploratory code switching", which she defines partly in terms of speakers' intentions, can be understood as a residual category (akin to Auer's (1984: 69) "polyvalent local meanings") in which the functions of switches are ambiguous to both participants and analysts.

Zentella (1997) divides switches into two basic categories based on whether or not they can be explained by "on the spot observables" (e.g. linguistic proficiency of an interlocutor or requirements of shifting settings). Those switches that occur in response to on the spot observables are what Gumperz and others have called "situational." Zentella's (1997: 83, 92) second category explains switches in terms of "conversational strategies," or "in the head communicational factors". These switches overwhelmingly serve as contextualization cues, marking changes in what Zentella (1997: 93), following (Goffman 1979: 5), calls "footing." In other words, this category is for unmarked discourse contextualizing switches. Like Auer (1984), Zentella (1997) has no category corresponding to metaphorical switching, reflecting similarities in the code switching patterns of the second-generation immigrant youth that both studied.

\section{Socio-political correlates of code switching types}

In addition to encompassing the categories of various analysts, these three general functional categories link code switching practices and meanings to particular sociopolitical contexts. Code switching is both a language contact phenomenon and a social contact phenomenon, and the occurrence, shape, distribution, and meanings of code switching vary across and within communities. Code switching practices and interpretations depend on members' access to cross-group social roles and domains and to groups' relative and situational interests in intergroup boundary-maintenance versus boundary-leveling (Heller 1988). The nature of these social boundaries and the social associations of particular codes - a result of specific histories of social relationships (Gal 1988) - correlate with the types of functions commonly served by code switching.

The children of many international labor migrants, for example, have access to both sending and host society languages and sociocultural roles and thus straddle national, linguistic, and ethnic boundaries. Code switching in this second generation is often frequent, intra-sentential, and unmarked in intra-group peer interactions, serving as a form of unmarked, discourse contextualization. ${ }^{7}$ (Poplack 1981, 1988; Gal 1988). The fact that such intra-group code switching is locally unmarked is not the same as saying that it lacks broader social meanings. In terms of identity, it is important to distinguish between local discursive functions of particular code switches and the more global, sociopolitical functions of code switching as a discourse mode (cf. Myers-Scotton 1993: 149; Zentella 1997: 101). The unmarked Spanish-English code switching of bilingual New York Puerto Ricans and Dominican Americans, for example, is a key index of ethnic, racial, and

\footnotetext{
${ }^{7}$ See Myers-Scotton (1993b: 119-125) for a description of urban, post-colonial African situations in which such unmarked switching occurs.
} 
political economic identity even though individual switches may only serve discourse contextualization functions.

In situations of more stable bi-/multi-lingualism, codes and social identities are often more highly compartmentalized, individuals have fewer opportunities to develop multiple roles and relationships across social boundaries, and there are higher sociopolitical costs for crossing boundaries. In such situations, code switching tends to be less frequent, inter-turn or inter-sentential rather than intra-sentential, and socially and linguistically marked. Studies in such social contexts (e.g. Kroskrity 1993; Heller 1992, 1995) emphasize the metaphorical and political/ideological nature of code switching, and do not employ a category of unmarked discourse contextualizing switches.

\section{Simultaneity of code switching functions}

Even in sociohistorical situations in which a particular function of code switching is most recurrent, however, individual switches can simultaneously (and ambiguously) fulfill multiple functions. The relative degrees to which the function/meaning of a switch is "brought along" to interaction versus "brought about" in an interaction itself (Auer 1992) can vary from switch to switch. I illustrate the ways in which code switching simultaneously and ambiguously conveys meaning(s) at multiple levels with two examples of switches among Dominican Americans. As described above, Dominican American code switching is often unmarked in peer interaction, fulfilling local discourse contextualization functions. Frequent use of code switching as an unmarked contextualization strategy, however, does not preclude other functions of code switching, such as identity negotiation, even in the informal, intra-group peer interactions in which unmarked switching is most common. In Example 5, a switch serves an unmarked discursive function - setting off a quotation - at the same time that it represents a highly marked metaphorical activity.

[(JS \#2 12:40:58) Janelle and Isabella are sitting outside their school building. Janelle has noticed some students staring in her direction. Their attention is likely attracted by the spectacle of her being videotaped.]

J: What's up with them people looking over here, them hicks? And stuff.

I: $\quad<$ No: hicks $>$.

$\mathrm{J}$ : What do you call a hick? Cause Jose says a hick is someone ridiculous, somebody stupid. Isn't a hick someone who just came back from the country and they can't really dress, they can't speak English? And they, you know,

I: $\quad$ They be like loca, loca, [e::\%:: ерa ], ерa::: , huepa: ((high pitched, nasal voice and crinkled nose for the Spanish words))

J: [Yeah, right?]

[[Translation: “honey, honey, he::::::::y, alright!, alri::::ght!, alri:ght!’]]

This code switch serves both a discourse contextualization function - framing a direct quotation - and a highly metaphorical function - constructing a positive Dominican 
American identity in opposition to a recent Dominican immigrant identity (cf. Zentella 1990, 1997 among Puerto Ricans). The use of code switching to set off quotations from surrounding talk has often been noted as a function of code switching, and many have noted that the code used for the quotation is not necessarily the code that the speaker originally used.

In this case, the code match between the quoted speech and original speech is of significance. Code switching here is not just a means of marking off the directly quoted speech, but a means of indexing social attributes and displaying stances associated with a particular use of a code (Ochs 1992). The lexical choice and prosodic and visual features of the quoted speech code switch (cf. Mitchell-Kernan 1972 on "marking" among African American) serve to index locally negative attributes: A stereotyped island Dominican backwardness that is stigmatized in a United States urban youth context (Bailey forthcoming). ${ }^{8}$

The ambiguity and multi-functionality of individual code switches is even more salient in the code switch (marked with an arrow) in 6), which can be seen as simultaneously situational, metaphorical, and unmarked discourse contextualizing.

[(WR \#2 1:20:07 Three students are sitting in class. Claudia is a Guatemalan American; Wilson is a Dominican American; Eduardo is a recent Dominican immigrant. Eduardo jokingly accuses Wilson of being Haitian, a playful insult directed at relatively Africandescent Dominicans in the Dominican Republic. Eduardo knows that Wilson is not Haitian. Claudia appears unsure of Wilson's identity in light of Eduardo's claim and Wilson's initial, joking support of that claim.)

Wilson: ((singing)) Dame del pollito ['Give me a little bit of that chicken'] Eduardo: $\quad$ Tú no dique eres de Haití? Tú no eres dominicano, Wilson.

['Aren't you supposedly from Haiti? You're not Dominican, Wilson.']

Wilson: Yo nací en Haití, ['I was born in Haiti,'] ((Wilson turns to E., smiling))

Eduardo: $\quad[(\quad)]$ ((motions toward camera, Wilson turns to camera))

Wilson: $\quad$ [pero me] crié en Santo Domingo.

['but I was brought up in the Dominican Republic']

((Eduardo holds up both hands, palms forward, with middle and ring fingers curled down the sign of the cuckold - behind Wilson's head; Wilson turns back toward Eduardo and hits him in the leg with the back of his open hand))

(1.5)

Claudia: $\quad$ So you're Haitian, huh?

Wilson: $\quad$ No I'm Dominican.

Claudia: $\quad$ You were born in DR? ['the Dominican Republic']

\footnotetext{
${ }^{8}$ Literature on code switching has historically emphasized the in-group connotations of the code used by the non-dominant/minority group in informal and family situations (e.g. Fishman et al. 1971; Gumperz 1982). In this case, in contrast, Spanish is being used to mock a fellow Spanish speaker and differentiate between a positive self and a disparaged "other," even though the "other" is a fellow Dominican immigrant and Spanish speaker. Although Isabella has lived in the Dominican Republic until age 6, was a fluent Spanish speaker, and had many monolingual relatives, including her mother, Spanish language is treated as indexing negative attributes in this specific interactional context.
} 
Wilson: Yeah.

Eduardo: $\quad$ Nació en Haití. [ ['He was born in Haiti.']

$\rightarrow$ Wilson: En Santo Domingo. ['In the Dominican Republic.']

Eduardo: Es haitiano. ['He's Haitian.']

Wilson: Es mentira, ven aca, a quién tú le vas - a quién tú le vas a creer, a mí o a estos dos locos? ((turning his head laterally first to one side then the other, indicating Eduardo and an accomplice on his other side.))

['It's a lie, come on, who are you going - who are you going to believe, me or these two crazy guys?']

Wilson's code switch En Santo Domingo can be explained as fulfilling multiple social/pragmatic functions. 1) On one level it serves as a situational switch. Eduardo, a recent immigrant, has limited English skills, and he and Wilson address each other only in Spanish in this class. Wilson speaks in English to Claudia, but when Eduardo re-enters the conversation with a Spanish language turn, Wilson switches to a language understood by both Claudia and Eduardo. 2) This switch can also be interpreted as an unmarked discourse contextualizing switch, which makes clear the connection of Wilson's turn to Eduardo's prior turn. Wilson's use of a code that matches that of Eduardo's utterance serves to display that he is addressing the same issue and responding to Eduardo's utterance. He othercorrects (Schegloff, Jefferson, \& Sacks 1977) Eduardo, linking his response to Eduardo's assertion not only through a parallel syntactic structure (en ...) but through use of the same code. 3) Wilson's switch also has metaphorical import related to his social identity. Wilson is of predominantly African descent, and in the Dominican Republic, adolescents may jokingly accuse relatively African-descent Dominicans of being Haitian, an identity that is highly disparaged there. ${ }^{9}$ Wilson's switch to Spanish - and his subsequent turn in Spanish addressed to Claudia - highlight his fluency in Spanish. This fluency, as well as aspects of his phonology, e.g. elision of syllable-final /s/, are commensurate with a Dominican identity but not a Haitian one. Both on the island (Gonzalez 1975) and in the United States, Dominicans treat the ability to speak Spanish as evidence of a Dominican or Spanish/Hispanic/Latino identity rather than an African/Haitian/Black American identity (Bailey 2000). From a Dominican interpretive framework, this display of Spanish speaking thus has a highly significant metaphorical meaning.

\section{Discourse contextualization in Dominican American code switching}

Although many Dominican American code switches serve situational and metaphorical functions, as in examples 6) and 7) above, most switches in bilingual peer interaction are of the unmarked discourse contextualization type. In the segments of Dominican American

9 Although up to $90 \%$ of Dominicans have African ancestry, Dominicans have historically emphasized their Spanish/European heritage and constructed their national/racial/ethnic identity in contradistinction to Haiti and Haitians (Moya Pons 1995, 1996; Silié 1989). For many Dominicans, Haitians count as Black/African while Dominicans are seen as European (and not Black), Haitians speak an AfricanFrench creole while Dominicans speak a European language, and Haitians practice African voodoo while Dominicans practice (European) Catholicism (Duany 1994: 67, 69). 
code switched interaction transcribed below, I highlight the locally negotiated and interactionally emergent functions of specific switches. Presentation and analysis of switches in their sequential, interactional context serves as an antidote to the sentence-based syntax bias in listing decontextualized switches under category headings. Presenting actual segments of discourse also captures contact phenomena beyond code switching, e.g. loanwords and phonological transference, that characterize the language of Dominican Americans.

In my analyses of these segments, I emphasize the conversational management techniques, e.g. repair (Schegloff, Jefferson, and Sacks 1977), that occupy significant parts of the talk and for which code switching is a resource (Auer 1995; cf. Milroy \& Wei 1995; Wei 1998; Alfonzetti 1998). Participants' noticeably attend to such conversational structures and management activities, and many switches occur at the initiation and conclusion of such activities, suggesting that such analysis can contribute to our understandings of the "when" and "why" of discourse contextualization switching.

\subsection{Interactional strategies in Dominican American code switching: Transcript 7}

In the following example, a switch into English occurs with the initiation of a repair sequence, and English is maintained until the end of the repair sequence, after which speakers switch back to Spanish.

[(FU \#1 12:06:13) Frangelica and Annie are sitting in physics class where they have been discussing in Spanish (without switches for many turns) the details of their respective eating habits. Translation is below the transcribed segment.]

F: $\quad$ Yo como mucho.

A: $\quad$ Yo no quiero. Yo quiero estar bien para mi prom.

F: Ah, yo tambien. Las uñas - tengo que [tratarlas bien. ]

A: $\quad$ [Tú no tienes que] ir con senior, right, no $(e s)$ ?

(.5) ((Frangelica does lateral headshakes))

A: $\quad[()]$

F: $\quad[Y o]$ soy un junior.

A: $\quad \mathrm{No}-$

F: $\quad<$ If you're a junior or a [senior- $>]=\quad(($ depresses fingers as she enumerates $))$

A: $\quad$ [Oh, okay]

F: $\quad$ =you could go with anybody.

A: Alright

F: But if you're not- a sophomore or a freshman, you have to get yourself a junior or a senior.

A: $\quad$ I see. (4.0)

A: $\quad(\quad)$ te vas a ir?

F: $\quad \mathrm{Mm} \mathrm{hmm/} \mathrm{Mm} \mathrm{hmm.}$ 
A: Para donde? Para comer? No, yo digo para comer- no yo digo para fuera chillin'?

F: $\quad$ Ah- parafuera?

[[Translation of segment 7):

F: $\quad$ I eat a lot.

A: I don't want to. I want to look good for my prom.

F: Oh my, me too. My nails- I have to [take care of them]

A: [You have to ] go with a senior, right, don't you?

(.5) ((Frangelica does lateral headshakes))

A: $\quad[(\quad)]$

F: $[\mathrm{I}]$ am a junior.

A: $\quad$ No-

(4.0)

A: $\quad(\quad)$ are you going?

F: $\quad$ Mm hmm.

A: Where to? To eat? No, I mean to eat- no, I mean outside chillin'?

F: $\quad$ Oh my- outside? ]]

The first two contact phenomena in this segment are Annie's "prom" and "senior," both loanwords with a source in Annie and Frangelica's United States high school experience. Annie then uses a tag switch (Poplack 1982) "right." Zentella (1997: 94) terms such switches "checking," in which "the shift seeks the listeners' opinion or approval." In this case, Annie is seeking something more interactionally specific and concrete than an "opinion" or "approval." She has offered a candidate understanding that she would like confirmed or rejected. Intersubjectivity in talk cannot be assumed by analysts because participants themselves do not assume it: They regularly display and continuously update intersubjective understandings (Heritage \& Atkinson 1984), e.g. through displaying candidate understandings, self- or other-initiated repair (Schegloff, Jefferson, \& Sacks 1977), displays of agreement or disagreement with assessments (Goodwin \& Goodwin 1992), etc. Annie's code switch serves to bracket prior discourse from the activity of requesting confirmation of a candidate understanding. Annie then switches back to Spanish no (es)?, reiterating her request, in translation, for confirmation of her candidate understanding. Such reiterations can serve to emphasize or clarify a message; in this case it is not propositional content that is the "message" that is emphasized, but a conversational activity: The request for confirmation of a displayed understanding.

As the first pair part of an adjacency pair, Annie's request makes an answer specifically a confirmation or rejection of her candidate understanding - conditionally relevant (Schegloff 1972). Both Annie and Frangelica treat a response as conditionally relevant, although it is not clear to Annie from Frangelica's initial response ("Yo soy un junior") to the request that she is oriented toward this conditional relevance. Annie's Nois an other-initiation of repair (Schegloff, Jefferson, \& Sacks 1977) directed at Frangelica's "Yo soy un junior." It is not directed at the truth value of Frangelica's statement but rather at its apparent failure to address the issue made relevant by Annie's code switched tag question(s).

Frangelica then switches into English, in a form of repair, to describe the rules for 
prom attendance. This switch coincides with the onset of slower tempo speech and gestures in which Frangelica uses the index finger of one hand to depress successive fingers on her other hand as she says "junior" and "senior," as if enumerating points in a logical argument. The switch into English, along with these prosodic and gestural features, coincides with initiation of a different discourse activity, a formal account of institutional rules. Discussion of school rules in the abstract (versus the more personal implications of such rules: Tú no tienes que ir con senior?) may favor English, but the switch itself may be the important issue, and the fact that it was to English simply a function of the prior speech being in Spanish.

Annie's overlapping backchannel response "Oh, okay" displays her changed understanding (Heritage 1984b) of the relevance of Frangelica's talk to the original tagquestion. She displays this changed understanding after Frangelica begins "If you're a junior or", even before Frangelica is able to state the rules for who can go to the prom with whom. Frangelica's switch to English, in conjunction with co-occurring contextualization cues, may function as a particularly powerful framing device to repair a misunderstanding, even before the relevant referential content is uttered.

Annie's subsequent questions about lunch-time plans, following a long gap, are in Spanish. The use of Spanish coincides both with a change in topic and a change in conversational activity. English had been used by Frangelica to repair difficulties resulting from her initial response to Annie's tag-request, and those problems have now been resolved. Even when speaking Spanish, however, Annie and Frangelica use lexical transfers, as in the first part of this segment, and Annie suggests that they go "para fuera chillin" " ['hanging out']. Frangelica does not treat the inflection of "chillin"" as unusual or marked, and consultants did not flag this form, although they agreed, when specifically questioned, that they would probably say para chilear ['in order to chill'] or "to/and chill."

\subsection{Interactional strategies in Dominican American code switching: Transcript 8}

In the following segment of transcript, switches again coincide with onset or conclusion of conversational management activities, and code choice can be predicted in part by the code used in prior sequence initiating activities.

[(FU \#1 12:08:39 This segment occurs two minutes after the one transcribed above. Annie and Frangelica have been taking part in various conversations in Spanish and English with Hispanic, Haitian, and Asian American classmates. Both are gazing at another classmate when Frangelica suddenly turns to Annie:]

F: Oh cómo está yendo tu trabajo? ['Oh, how is your work going?']

A: ( [Spanish language?] )

F: Ay Dios mío! Todavía? ['Oh my God! Still?']

A: <Todavía ['Still'] I want money for (the) prom. ((mock anguish))

F: Ay, el prom es en/in May. ['Oh my, the prom is in May.']

A: $\quad$ I want $<$ money. $>>^{\circ}$ Yeah. $<$ Yo creo que empezamos al final de este mes.

['I think we're going to start at the end of this month.']

F: $\quad \mathrm{Mm} \mathrm{hmm}$ 
A: I think I'm gonna save like three checks, to buy my- to buy [my shit.]

$\mathrm{F}$

$[A y$, pe $]$ ro three

checks, si tú trabajas bien, son [( )] ['Oh my, but ...if you work a lot, that's..']

A: [Cien]to pico. ['One hundred something']

F: $\quad(($ nods $))$

A: Por eso, yeah. ['That's why,...']

A: I think I'm gonna- I'm gonna save like three checks to buy my shit for the prom.

F: $\quad$ Mm.

F: Bueno. ['okay']

A: I don't know if I'm going anyway, you know what I'm saying?

F: $\quad$ Mm.

A: Cause like I want to go with somebody, like a date, (like) I don't want to go alone and stuff, so I don't know.

(6.0)

F: $\quad$ Si tú vas con Victor, te paga la entrada.

['If you go with Victor, he'll pay for your ticket']

A: $\quad$ I need a date ((laughing))

(3.0)

F: Él tiene un raid. ['He has access to transportation.']

(10.0) ((Annie next addresses another classmate in English.)

Anthropological and sociological accounts of code switching have generally focused on the absence or occurrence of switches in particular social contexts or communities, with particular situational or metaphorical functions, rather than on the absence or occurrence of switches in particular sequential contexts. In contexts in which switching is argued to be an unmarked discourse mode in its own right, the absence of switches can serve as a resource for analysis just as their occurrence can.

In this sequence the location of Annie's switch in her second turn ("Todavía. I want money...") is analytically meaningful in part because of where it does not occur. Frangelica completed her prior turn by proffering a candidate understanding of Annie's work situation in Spanish (Todavía?). In this instance Annie's not switching to confirm Frangelica's candidate understanding Todavía? - a second pair part - helps to both display her precise understanding of Frangelica's confirmation request and unambiguously confirm it. Her subsequent utterance in the same turn is in English ("I want money for the prom"). This code switched utterance initiates a new sequence and does not need to be so exquisitely tailored to display understanding of the prior turn and relevance to it. Auer $(1995,1998)$ finds that not all sequential junctures are equally likely to contain a switch, e.g. second parts of adjacency pairs (Schegloff \& Sacks 1973) are less likely to be switched than turns that initiate sequences, suggesting a distribution of switching that can be described in relationship to specific conversational sequences. Code switching may thus have a sequential preference organization as do other conversational activities (Levinson 1983: 307).

Frangelica responds to Annie's mention of the prom in a base/matrix language (based on the determiner, verb, and, consequently, verb inflection (Romaine 1995: 145)) of Spanish with two English lexical transfers. Although this utterance occurs in a sequence 
that was initiated in English, it is not directly made relevant by Annie's statement in the way that first pair parts (e.g. requests) make second pair parts (e.g. acceptance/rejection) conditionally relevant, so the switch is not occurring as a direct and obligatory response to the prior turn.

Annie continues speaking in English, repeating her plaint "I want money." Such reiteration suggests that Frangelica's turn did not address Annie's original "I want money for the prom" in a way that would encourage further development of a specific "talking about needing money for the prom" sequence. This reiteration serves as a form of repair to re-establish such a sequence. This repetition, however, does not address the surprise/distress that Frangelica displays in her turn at the rapid approach of the upcoming prom. Annie subsequently acknowledges Frangelica's turn with "Yeah", bracketing it as a distinct discursive activity with prosodic marking, i.e. a lower volume and accelerated tempo.

Annie switches to Spanish, in the same turn, to say when she thinks she will start working. This utterance links conceptually to her need for money, but it also serves as a response to Frangelica's exclamation regarding the rapidly approaching prom date. The use of Spanish may be favored as a response to Frangelica's Spanish utterance, and it may more effectively link her utterance to the initial two turns of this segment which were in Spanish and about Annie's work.

Annie switches back to English to discuss her specific plans for allocation of paychecks for the prom. Although this is a "switch" of code from the last words of her prior turn, it is arguably the maintenance of the code in which she chose to initiate talk - and will maintain throughout this segment - about money for the prom. Annie has twice stated that she wants money for the prom, but Frangelica has not asked her specifics about her money needs that would enable to discuss the allocation of checks as a response to a question. Frangelica interrupts her in Spanish to suggest that three checks might not be the appropriate number to save. This switch marks the initiation of a new sequence - an otherinitiated repair. In terms of the preference organization of repair more generally, any form of other-initiation is less preferred than self-initiation (Schegloff, Jefferson, \& Sacks 1977), and the switch to Spanish may draw attention to the point of contention that Frangelica is making in questioning the number of checks needed to cover prom costs.

Despite speaking Spanish, Frangelica uses the English lexical transfers "three checks," duplicating the phrase from Annie's prior turn. Approaches to code switching and transfer that rely on isolated utterances and treat switches as a function of a) speaker language fluency, b) domains of language usage, and/or c) conversational strategies that pre-exist in the speaker's head account for this type of switch/transfer poorly. Such taxonomies suffer from their

failure to consider adequately the sequential implicativeness of language choice in conversation, i.e. the fact that whatever language a participant chooses for the organization of his/her turn, or for an utterance which is part of the turn, the choice exerts an influence on subsequent language choices by the same or other speakers. (Auer 1984: 5)

Zentella (1997) takes into account sequential implicativeness of language use in classifying one particular type of switch, "parallelism," in which a speaker copies a prior speaker's switch: 
A: You sleep with los ojos abiertos? (['your eyes open?'])

B: So, people die with ojos abiertos! (['eyes open']) (Zentella 1997: 97)

Although Zentella recognizes the significance of sequential context in isolating and labeling this type of switch, she classifies it as a form of "Crutch-like Code Switching," grouping it with switches in which a speaker does not know, or momentarily can't remember, a particular word. Such switches that produce parallel forms are not necessarily evidence of "crutching," with its connotations of compensating for a weakness. Such parallelism may represent, instead, a sophisticated means of maintaining conversational coherence and intersubjectivity. Building one's response to an interlocutor's turn around identical forms (not just the same referents) displays unequivocally that one has heard the prior turn and helps display that one is talking about the same thing(s) as other speakers.

Such parallelism occurs in several interactions in my data:

(JS \#2 11:12:40)

Jose: $\quad$ Es que a tí te duele todo, man. ['It's just that everything hurts you...'] Janelle: $\quad$ Es que I'm telling you I'm fragile. ['It's just that I'm telling you....']

In this case Janelle uses Es que to introduce her claim that she is fragile. This Es que has little propositional content, but it displays her attendance to Jose's turn and allows her to use his precise words to counter his criticism of her.

In the following example, parallelism helps Jose to display his understanding of Janelle's turn and the coherence of his turn with hers.

(JS \#2 10:55:23)

Janelle: $\quad$ Tengo sueño. ['I'm sleepy.']

Jose: $\quad$ You always got sueño. ['You're always sleepy.']

Jose switches or transfers for sueño. In this case, the use of sueño not only displays understanding of the prior utterance, it saves Jose from a problematic English structure. Jose begins an English phrasal calque of Tienes siempre sueño, which parallels the structure used by Janelle, but which can only be completed awkwardly in English:

*You always got sleepiness.

Intrasentential switching is frequent in talk between Janelle and Jose, so this code switch may be less marked than, and therefore preferable to, an utterance awkwardly completed in English.

In transcript 8), Francisca's use of the English "three checks" in a turn that is otherwise in Spanish serves to connect her initiation of repair to Annie's prior English turn. Annie switches (from her prior English turn) to Spanish to complete the repair that Frangelica has initiated in Spanish. Francisca's repair initiation turn employs a compound turn constructional unit (Lerner 1991, 1996) with an "if" component (si tú trabajas ...) that projects the final shape of her turn. Spanish is the code that Frangelica has used to initiate 
this conversational activity, and Annie maintains its use to complete Frangelica's utterance semantically, syntactically and in the same code, displaying precise understanding of Frangelica's turn even as it develops. Among bilinguals, there may be a preference for same code use in collaborative turn completion, just as there is a preference for second pair parts to match the code of first pair parts.

Frangelica displays agreement with the monetary figure given by Annie by nodding. Annie continues in Spanish, Por eso, treating her prior turn as an explanation as to why "three checks" were an appropriate number to save for the prom. Her subsequent "yeah" displays Annie's acknowledgment of Frangelica's nod of agreement with Annie's explanation, suggesting that they now share a common understanding. Annie then continues in English, repeating virtually word-for-word her pre-repair sequence utterance, that she thinks she's going to save three checks to buy her things for the prom. Use of English serves to set this utterance off from the repair sequence, and it may more effectively orient Frangelica back to the activity that Annie previously initiated in English but to which Frangelica responded only by initiating repair. Frangelica gives only noncommittal responses ("Mm"/Mm and Bueno) to Annie's subsequent talk in English of the problems she faces in going to the prom: Money and the need for a date.

After the repair sequence (effected in Spanish following Frangelica's initiation of it in Spanish), this interaction develops a pattern of non-reciprocal language use (Gal 1979), Annie speaking in English and Frangelica in Spanish. Zentella (1997) suggests that such non-reciprocal conversation can index more formal or distancing discourse in some situations among bilinguals. In this case, non-reciprocal talk coincides with Frangelica displaying little enthusiasm for Annie's concerns about the upcoming prom (whether she's going, whom she's going with), and Annie treating Frangelica's suggestion of Victor as a companion as inappropriate. After a six second gap, Frangelica suggests in Spanish that Annie could go to the prom with Victor. She does not define him as a "date," which is what Annie has been talking about, but rather as someone who would pay for her ticket. Annie responds in English that she needs "a date" and laughs, implicitly treating Victor as an inappropriate partner for the prom, whether date or not. After a gap of three seconds, Frangelica volunteers in Spanish that Victor has access to transportation (of some significance on prom night), but Annie does not respond. Frangelica takes the stance that Victor is someone who can minimally pay for Annie's ticket and give her a ride, providing an opportunity for Annie to display a congruent stance and alignment with Frangelica, but she does not do so, highlighting this lack of alignment through a non-reciprocal code switch.

\subsection{Interactional strategies in Dominican American code switching: Transcript 11}

The following segment illustrates the use of code maintenance and switching to organize specific sequences and to achieve a common understanding of a third-party referent, Diana/Diana who is variously referred to as /dayæn $/$, /dayana/, and /diana/, reflecting American English, hybrid English/Spanish, and Spanish pronunciations of her name. Paradoxically, code switching in this instance is used in repairing difficulties that are a result of the very bilingualism of the interlocutors to begin with. While Alejandro uses pronunciations of Diana's name that are assimilated to English, Pamela recognizes the 
referent only in an unassimilated Spanish pronunciation.

(LD\#1 11:47:25) [Alejandro and his Dominican American friend Jonathan are trying to sell tickets between classes to a school-sponsored roller skating party. Alejandro calls out to Pamela in the hallway between classes.]

A: You gonna go?

P: Y tú? ['And you?']

A: You gonna go?

P: $\quad$ I wanna go, but I don't wanna go by myself.

A: What do you mean you don't want ( )

P: $\quad(\quad)$

A: I'm gonna be there!

P: $\quad$ Yeah, but you're gonna be with your friends

A: No I'm not.

P: Yes.

Jo: Nuh uh.

A: Jonathan's going

Jo: (He's) going. ((indicating Alejandro))

A: Jo- Diana's /dayæn^z/ going.

(.8)

A: Oístes? ['Did you hear?']

$(.5)$

A: Diana /dayana/ $\underline{v a}$. ['Diana is going.']

P: Qué Diana /dayana/? ['What/Which Diana?']

A: Diana /dayana/

P: Qué Diana /dayana/? ['What/Which Diana?']

A: Yeah, Diana /dayana/ ( ) la Claudia,

P: Diana! /diana/

A: Diana /diana/, Diana, Diana

P: Y ella va para allá? ['And she is going there?']

A: Yeah

P: O::h. Y que nos juntamos aquí? ['And we're supposed to meet here?']

A: I'm selling the tickets, four dollars.

This segment is organized around getting from a pre-offer/announcement, made in the first line ("You going?"), to the actual offer/announcement, in the last line ("I'm selling the tickets, four dollars."). While such pre-sequences can take as few as two turns (e.g. A: You going? B: Yes.), various nested insertion sequences (Schegloff 1972) here - regarding who is going to be on the roller-skating trip - separate the initiation of the sequence from the actual offer/announcement.

Alejandro initiates the pre-sequence with a request in English, but Pamela counters with her own request, in Spanish, initiating an insertion sequence. While there is a preference among bilinguals for second pair parts of adjacency pairs to match the language of first pair parts, Pamela is not giving a second pair part, but rather initiating her own 
sequence. Alejandro treats the insertion sequence as closed by reiterating his pre-offer, and both Alejandro and Pamela subsequently treat Alejandro's attendance as given information, suggesting that Alejandro gave an affirmative visual signal, e.g. vertical head nod to answer Pamela's first pair part request $Y$ tú? (the camera was not directed at Alejandro at that moment).

After debating whether Alejandro would spend time with Pamela at the skating event and noting that Jonathan was going, Alejandro states that "Diana's going." This statement refers back to Pamela's initial utterance of the insertion sequence, "I wanna go, but I don't wanna go by myself." Alejandro's "Diana's going," however, leads to a new kind of trouble and new insertion sequences, concerned with repair and achieving a common understanding of the referent of "Diana."

Following Alejandro's mention of Diana going, there is a gap of .8 seconds, suggesting some sort of interactional trouble, e.g. misunderstanding or impending dispreferred sequences. Alejandro treats Pamela's lack of response to his announcement as meaningful, as if his mention that Diana was going should have led to a response from her. He switches to Spanish, initiating a repair (Oístes? ['Did you hear?']). He then repeats the same phrase in Spanish "Diana va."

Such translation code switches are one of the six types listed by Gumperz (1982) and the single most frequent type of switch in Zentella's (1997) data. Both analysts treat these translations/reiterations as forming a single turn, as if produced by an isolated speaker, without annotation of non-verbal behavior or the conversational gaps that are typical between the switched segments of such reiterations:

No me crees? You don't believe me? (Zentella 1997: 96)

Keep straight. Sidha jao. [English-Hindi] (Gumperz 1982: 78)

The interactive nature of this type of switch is particularly clear in the above transcript because of the gaps between turns, and because Alejandro calls attention specifically to his interlocutor's behavior (Oístes? ['Did you hear?']) before the reiteration.

Alejandro's reiteration in Spanish (Diana /dayana/ $\underline{v a}$ ) does not lead to a shared understanding, and Pamela other-initiates another repair sequence with the first pair part, Qué Diana? Alejandro's second pair part is a reiteration of "Diana." While Alejandro uses an American English pronunciation of Diana in his first turn, he then shifts to a hybrid English-Spanish pronunciation for his next three utterances. He maintains the English /ay/ as the initial diphthong but uses a Spanish /a/ for the second two vowel sounds (/dayana/), a pronunciation that Pamela duplicates as she tries to identify its referent in repair initiations. Pamela once again initiates repair Qué Diana?. Alejandro treats Pamela's utterance as a correct candidate understanding, by confirming it with "Yeah" and reiterating "Diana."

Only when Alejandro names another student with intonation and prosody that suggests that he is enumerating a list (of known associates of Diana) does Pamela identify the referent of Diana, a student she calls Diana /diana/. Alejandro verifies this candidate understanding by repeating her name with Spanish phonology three times. Pamela then proffers another candidate understanding $Y$ ella va para allá?. Alejandro again confirms this candidate understanding, this time in English. Pamela displays her changed state of 
understanding with the English token "Oh" then initiates another insertion sequence in Spanish regarding further details of the trip: Y que nos juntamos aquí?

Alejandro does not respond to her initiation of yet another insertion sequence, but instead treats Pamela's expressed change of state ("Oh") as satisfying the original conditions which prevented her from agreeing to go ("I wanna go, but I don't wanna go by myself"). Thus freed from the conditions/hesitations set up in Pamela's initial insertion sequences, Alejandro makes the offer/announcement ("I'm selling the tickets, four dollars.") which was basis of the pre-offer ("You gonna go?") that launched the entire sequence. Although various insertion sequences were executed in Spanish, or Spanish and English, the announcement/offer of the last line is made in the code of the pre-offer.

\subsection{Sequential preferences in Dominican American code switching}

Data presented here suggest interactional patterns of code switching to be further explored among groups who use relatively frequent code switching for discourse contextualization. A first pattern is the tendency for other-initiation of repair to coincide with code switching:

(from example 7)

$\mathrm{F}: \quad[Y o]$ soy un junior.

A: $\quad \mathrm{No}-$

F: $\quad$ If you're a junior or a [senior- $>$ ] = ((counts fingers as she enumerates))

A: $\quad$ [Oh, okay ]

F: $\quad$ =you could go with anybody.

(from example 8)

A: I think I'm gonna save like three checks, to buy my- to buy [my shit .]

F:

si tú trabajas bien, son $\quad$ [( $\quad)]$ [ay: oh my; goodness!]

A: [Cien] to pico.

F: $\quad(($ nods $))$

A: Por eso, yeah.

A: I think I'm gonna- I'm gonna save like three checks to buy my shit for the prom.

(from example 11)

A: Jo- Diana's /daiæn^z/ going.

(.8)

A: Oístes? ['Did you hear?']

$(.5)$

A: Diana /dayana/ $\underline{v a}$. ['Diana is going!']

In their study of a Chinese immigrant community in England, Milroy and Wei (1995: 14850) find code switching to serve as 1) a means of marking dispreferred responses, particularly by the English-born in response to their parents, and 2) a means of marking other-initiated repair or other-repair, particularly among adult speakers (1995: 150-1). The type of repair presented in examples 7), 8), and 11) - other-initiated other-repair - is the 
least preferred form of repair (Schegloff, Jefferson, \& Sacks 1977). These switches thus coincide both with dispreferred and repair sequences, commensurate with the findings of Milroy \& Wei (1995), but they also show that such switches can occur among peers.

A second pattern suggested by data presented here is that specific communicative sequences (as opposed to the overall interaction) may have a "base language." Code switches may coincide with a) the beginning of insertion sequences and b) the resumption of sequences that had been temporarily suspended for insertion sequences. This pattern is particularly evident in example 8) in which Annie not only uses the same code, but almost the identical words after insertion sequences:

"I'm gonna save like three checks to buy my shit for the prom."

It is also suggested by Alejandro's code use in example 11) in maintaining his pre-sequence and eventual offer/announcement in one code despite their separation by multiple insertion sequences:

A: You gonna go? [Pre-Offer/Announcement sequence initiation]

P: $\quad Y$ tú? [Insertion with code switch]

A: You gonna go? [Pre-sequence]

[Multiple insertion/repair sequences, many of them in Spanish.]

A: I'm selling the tickets, four dollars. [Offer/Announcement]

Milroy \& Wei (1995: 152) give examples of code switching marking the boundary between presequences and target sequences, but in the examples they give, the target sequence immediately follows the pre-sequence. In the examples given here, there is no need to mark a boundary between pre- and target-sequences, because they are already separated by multiple turns involved in repair or insertion sequences. The greater conversational exigency, in these cases, is establishing coherence between the pre-sequence and subsequent parts of the sequence, an exigency that may be better met by matching the code of the two conversational structures after intervening sequences in a distinct code.

\section{Conclusions}

Formal definitions of code switching veil the diversity of practices and functions that code switching encompasses. Both the shapes and meanings of switching vary across communities and specific social and discursive contexts. Dominican American high school students code switch in response to visible changes in situation, for metaphorical purposes, and as a means of contextualizing communicative contributions to their on-going interactions. I have focused on this last dimension of code switching - discourse contextualization - in which switching is part of the nuts-and-bolts work, e.g. achieving repairs, done by interlocutors to maintain a degree of intersubjectivity, a task of all conversation. This form of switching is common in Dominican American peer interaction, but it represents a dimension of switching that has been underexplored in the bilingual talk of United States Latinos. 


\section{References}

Aarsleff, Hans (1982) Introduction. In H. Aarsleff, From Locke to Saussure: Essays on the Study of Language and Intellectual History. Minneapolis: University of Minnesota Press, pp. 3-41.

Alfonzetti, Giovanna (1998) The conversational dimension in code-switching between Italian and dialect in Sicily. In Peter Auer (ed.), Code-Switching in Conversation: Language, Interaction, and Identity. London and New York: Routledge, pp. 180-211.

Alvarez-Cáccamo, Celso (1998) From 'switching code' to 'code-switching': Towards a reconceptualisation of communicative codes. In J.C. Peter Auer (ed.), Code-Switching in Conversation: Language, interaction and identity. New York: Routledge, pp. 29-48.

Atkinson, J. Maxwell and Paul Drew (1979) Order in Court: The Organisation of Verbal Interaction in Judicial Settings. London: Macmillan.

Auer, J.C. Peter (1984) Bilingual Conversation. Amsterdam/Philadelphia: John Benjamins Publishing Company.

Auer, J.C. Peter (1988) A conversation analytic approach to codeswitching and transfer. In M. Heller (ed.), Codeswitching: Anthropological and Sociolinguistic Perspectives. New York: Mouton de Gruyter, pp. 187213.

Auer, J.C. Peter (1992) Introduction: John Gumperz's approach to contextualisation. In P. Auer and A. di Luzio (eds.), The Contextualisation of Language. Amsterdam: John Benjamins Publishing Company, pp. 1-38.

Auer, J.C. Peter (1995) The pragmatics of code-switching: A sequential approach. In Lesley Milroy and Pieter Muysken (eds.), One Speaker, Two Languages: Cross-disciplinary Perspectives on Code-Switching. Cambridge: Cambridge University Press, pp. 115-135.

Auer, J.C. Peter (1998) Introduction: Bilingual conversation revisited. In J.C. Peter Auer (ed.), Code-Switching in Conversation: Language, interaction and identity. New York: Routledge, pp. 1-24.

Auer, J.C. Peter (ed.) (1998) Code-Switching in Conversation: Language, Interaction and Identity. New York: Routledge.

Austin, J.L. (1962) How to Do Things with Words. Oxford: Oxford University Press.

Bailey, Benjamin (2000) Language and negotiation of ethnic/racial identity among Dominican Americans. Language in Society 29.4.

Bailey, Benjamin (forthcoming) Multi-variety language and multiple identities of Dominican Americans. Journal of Linguistic Anthropology.

Bateson, Gregory (1972) Steps to an Ecology of Mind. New York: Ballantine.

Blom, Jan-Peter, and John Gumperz (1972) Code-switching in Norway. In J. Gumperz and D. Hymes (eds.), Directions in Sociolinguistics. New York: Holt, Rinehart and Winston, pp. 407-34.

Bloomfield, Leonard (1933) Language. New York: Henry Holt and Company.

Chomsky, Noam (1965) Aspects of the Theory of Syntax. Cambridge, MA: MIT Press. 
Clyne, Michael (1987) Constraints on code switching: How universal are they? Linguistics 25: 739-64.

Duany, Jorge (1994) Ethnicity, identity, and music: An anthropological analysis of the Dominican Merengue. In Gerhard Behague (ed.), Music and Black Ethnicity: The Caribbean and South America. New Brunswick: Transaction Publishers, pp. 65-90.

Duranti, Alessandro (1993) Intentionality and truth: An ethnographic critique. Cultural Anthropology 8: 21445.

Duranti, Alessandro, and Charles Goodwin (eds.) (1992) Rethinking Context: Language as an Interactive Phenomenon. Cambridge: Cambridge University Press.

Ferguson, Charles A. (1959) Diglossia. Word 15: 325-40.

Fishman, Joshua, R.L. Cooper, and R. Ma (1971) Bilingualism in the Barrio. Bloomington: Indiana University Press.

Franceschini, Rita (1998) Code-switching and the notion of code in linguistics: Proposals for a dual focus model. In J.C. Peter Auer (ed.), Code-Switching in Conversation: Language, interaction and identity. New York: Routledge, pp. 51-72.

Gal, Susan (1979) Language Shift. New York: Academic Press.

Gal, Susan (1988) The political economy of code choice. In M. Heller (ed.), Codeswitching: Anthropological and Sociolinguistic Perspectives. New York: Mouton de Gruyter, pp. 245-264.

Garfinkel, Harold (1967) Studies in Ethnomethodology. Englewood Cliffs, NJ: Prentice-Hall.

Goffman, Erving (1974) Frame Analysis: An Essay on the Organization of Experience. New York: Harper and Row.

Goffman, Erving (1981) Forms of Talk. Philadelphia: University of Pennsylvania Press.

Gonzalez, Nancie (1975) Patterns of Dominican Ethnicity. In John Bennett (ed.), The New Ethnicity: Perspectives from Ethnology (1973 Proceedings of The American Ethnological Society). New York: West Publishing Company, pp. 110-123.

Goodwin, Charles (1981) Conversational Organization: Interaction Between Speakers and Hearers. New York: Academic Press.

Goodwin, Charles, and Alessandro Duranti (1992) Rethinking context: An introduction. In A. Duranti and C. Goodwin (eds.), Rethinking Context: Language as an Interactive Phenomenon.Cambridge: University of Cambridge Press, pp. 1-42.

Goodwin, Charles, and M.H. Goodwin (1992) Assessments and the construction of context. In A. Duranti and C. Goodwin (eds.), Rethinking Context: Language as an Interactive Phenomenon.Cambridge: University of Cambridge Press, pp. 147-189.

Gumperz, John (1982) Discourse Strategies. New York: Cambridge University Press.

Gumperz, John (1992) Contextualization and understanding. In A. Duranti and C. Goodwin (eds.), Rethinking Context: Language as an Interactive Phenomenon. Cambridge: University of Cambridge Press, pp. 229-252. 
Gumperz, John, and Dell Hymes (eds.) (1972) Directions in Sociolinguistics: The Ethnography of Communication. New York: Basil Blackwell.

Gumperz, John, and Eduardo Hernández-Chavez (1975) Cognitive aspects of bilingual communication. In Hernández-Chavez, Beltramo, and Cohen (eds.), El Lenguaje de los Chicanos. Arlington, VA: Center for Applied Linguistics, pp. 154-163.

Heller, Monica (1988) Introduction. In M. Heller (ed.), Codeswitching: Anthropological and Sociolinguistic Perspectives. New York: Mouton de Gruyter, pp. 1-24.

Heller, Monica (1992) The politics of code-switching and language choice. In Carole Eastman (ed.), Codeswitching. Cleveland, Avon: Multilingual Matters, pp. 123-142.

Heller, Monica (1995) Language choice, social institutions, and symbolic domination. Language in Society 24.3: 373-406.

Heritage, John (1984a) Garfinkel and Ethnomethodology. Cambridge: Polity Press.

Heritage, John (1984b) A change-of-state token and aspects of its sequential placement. In J. Atkinson \& J. Heritage (eds.), Structures of Social Action: Studies in Conversation Analysis. Cambridge: Cambridge University Press, pp. 299-345.

Heritage, John, and J.M. Atkinson (1984) Introduction. In Atkinson and Heritage (eds.), Structures of Social Action: Studies in Conversation Analysis. Cambridge: University of Cambridge Press, pp. 1-15.

Hill, Jane, and Kenneth Hill (1986) Speaking Mexicano: Dynamics of Syncretic Language in Central Mexico. Tucson: The University of Arizona Press.

Keenan, Elinor Ochs (1976) The universality of conversational postulates. Language in Society 5: 67-80.

Kroskrity, Paul (1993) Language, History, and Identity: Ethnolinguistic Studies of the Arizona Tewa. Tucson: University of Arizona Press.

Labov, William (1971) The notion of 'system' in creole languages. In D. Hymes (ed.), Pidginization and Creolization of Languages. Cambridge: Cambridge University Press, pp. 447-72.

Lerner, Gene H. (1991) On the syntax of sentences-in-progress. Language in Society 20: 441-458.

Lerner, Gene H. (1996) On the 'semi-permeable' character of grammatical units in conversation: Conditional entry into the turn space of another speaker. In E. Ochs, E.A. Schegloff and S.A. Thompson (eds.), Interaction and Grammar. Cambridge: Cambridge University Press, pp. 238-276.

Levinson, Stephen (1983) Pragmatics. Cambridge: Cambridge University Press.

Lipski, John (1985) Linguistic Aspects of Spanish-English Language Switching. Tempe: Arizona State University, Center for Latin American Studies.

McClure, Erica (1977) Aspects of code-switching in the discourse of bilingual Mexican-American children. In M. Saville-Troike (ed.), Linguistics and Anthropology, GURT. Washington, DC: Georgetown University Press, pp. 93-115.

Meeuwis, Michael, and Jan Blommaert (1994) The "markedness model" and the absence of society. Multilingua 13: 387-423. 
Milroy, Lesley and Li Wei (1995) A social network approach to code-switching: The example of a bilingual community in Britain. In Lesley Milroy and Pieter Muysken (eds.), One Speaker, Two Languages: Crossdisciplinary Perspectives on Code-Switching. Cambridge: Cambridge University Press, pp. 137-157.

Mitchell-Kernan, Claudia (1972) Signifying, loud-talking, and marking. In Kochman (ed.), Rappin' and Stylin' Out: Communication in Urban Black America. Champaign, IL: University of Illinois Press, pp. 315-335.

Morgan, Marcyliena (1996) Conversational signifying: Grammar and indirectness among African American women. In Ochs, Schegloff, \& Thompson (eds.), Interaction and Grammar. New York: Cambridge University Press, pp. 405-34.

Moya Pons, Frank (1995) The Dominican Republic: A National History. New Rochelle, NY: The Hispaniola Book Corporation.

Moya Pons, Frank (1996) Dominican national identity: A historical perspective. Punto 7 Review: A Journal of Marginal Discourse 3(Fall).1: 14-25.

Myers-Scotton, Carole (1993a) Dueling Languages: Grammatical Structure in Codeswitching. Oxford: Oxford University Press.

Myers-Scotton, Carole (1993b) Social Motivations for Codeswitching: Evidence from Africa. Oxford: Oxford University Press.

Ochs, Elinor (1979) Transcription as theory. In Elinor Ochs and Bambi Schieffelin (eds.), Developmental Pragmatics. New York: Academic Press, pp. 43-72.

Ochs, Elinor (1992) Indexing gender. In A. Duranti \& C. Goodwin (eds.), Rethinking Context: Language as an Interactive Phenomenon. New York: Cambridge University Press, pp. 335-58.

Ochs, Elinor, Emanuel Schegloff, \& Sandra Thompson (eds.) (1996) Interaction and Grammar. New York: Cambridge University Press.

Pfaff, Carole (1979) Constraints on language mixing. Language 55: 291-318.

Poplack, Shana (1981) Syntactic structure and social function of codeswitching. In Richard Durán (ed.), Latino Language and Communicative Behavior. Norwood, NJ: ABLEX, pp. 169-184.

Poplack, Shana (1982) [1980] "Sometimes I'll start a sentence in Spanish y termino en español": Toward a typology of code-switching. In J. Amastae and L. Elías-Olivares (eds.), Spanish in the United States: Sociolinguistic Perspectives. New York: Cambridge University Press, pp. 230-263.

Poplack, Shana (1988) Contrasting patterns of codeswitching in two communities. In M. Heller (ed.), Codeswitching: Anthropological and Sociolinguistic Perspectives. New York: Mouton de Gruyter, pp. 215244.

Poplack, Shana, David Sankoff, and Christopher Miller (1988) The social correlates and linguistic consequences of lexical borrowing and assimilation. Linguistics 26.1: 47-104.

Psathas, G. (ed.) (1979) Everyday language: Studies in Ethnomethodology. New York: Irvington.

Romaine, Suzanne (1995) (2nd Edition). Bilingualism. Cambridge, MA: Basil Blackwell.

Rosaldo, Michelle (1982) The things we do with words: Ilongot speech acts and speech act theory in philosophy. Language in Society 11: 203-37. 
Sacks, Harvey, Emanuel Schegloff, \& Gail Jefferson (1974) A simplest systematics for the organization of turn-taking in conversation. Language 50.4: 696-735.

Sankoff, D., and S. Poplack (1981) A formal grammar for code-switching. Papers in Linguistics 14: 3-46.

Schegloff, Emanuel (1972) Sequencing in conversational openings. In Gumperz \& Hymes (eds.), Directions in Sociolinguistics: The Ethnography of Communication. New York: Basil Blackwell, pp. 346-80.

Schegloff, Emanuel, Gail Jefferson, \& Harvey Sacks (1977) The preference for self-correction in the organization of repair in conversation. Language 53: 361-82.

Schegloff, Emanuel, and Harvey Sacks (1973) Opening up closings. Semiotica 7.4: 289-327.

Schenkein, J.N. (ed.) (1978) Studies in the Organization of Conversational Interaction. New York: Academic Press.

Searle, John (1969) Speech Acts: An Essay in the Philosophy of Language. Oxford: Oxford University Press.

Sebba, Mark (1993) London Jamaican. Harlow, England: Longman.

Silié, Rubén (1989) Esclavitud y prejuicio de color en Santo Domingo. Boletin de Antropologia Americana 120: 163-70.

Silverstein, Michael (1976) Shifters, linguistic categories, and cultural description. In Keith Basso \& Henry Selby (eds.), Meaning in Anthropology. Albuquerque: University of New Mexico Press, pp. 11-56.

Stroud, Christopher (1992) The problem of intention and meaning in code-switching. Text 12.1: 127-155.

Stroud, Christopher (1998) Perspectives on cultural variability of discourse and some implications for codeswitching. In Peter Auer (ed.), Code-Switching in Conversation: Language, Interaction, and Identity. London and New York: Routledge, pp. 321-348.

Wei, Li (1994) Three Generations, Two Languages, One Family. Clevedon, England: Multilingual Matters.

Wei, $\operatorname{Li}(1998)$ The 'why' and 'how' questions in the analysis of conversational code-switching. In Peter Auer (ed.), Code-Switching in Conversation: Language, Interaction, and Identity. London and New York: Routledge, pp. 156-176.

Weinreich, Uriel (1953) Languages in Contact: Findings and Problems. New York: The Linguistic Circle of New York.

Wolfson, Nessa (1982) CHP: The Conversational Historical Present Tense in American English Narrative. Dordrecht: Foris.

Zentella, Ana Celia (1990) Returned migration, language, and identity: Puerto Rican bilinguals in Dos Worlds/Two Mundos. In F. Coulmas (ed.), Spanish in the USA: New Quandaries and Prospects. International Journal of the Sociology of Language 84: 81-100.

Zentella, Ana Celia (1997) Growing Up Bilingual: Puerto Rican Children in New York. Malden, MA: Blackwell Publishers. 